Professional paper

Stanislav Tedeschi, Davor Malus, Dražen Vouk

\title{
Final treatment of wastewater sludge in the City of Zagreb
}

Total sludge disposal costs are quite considerable in case of large-size wastewater treatment plants, where they are approximately equal to personnel costs. The problems relating to the Zagreb wastewater treatment plant are methodically analyzed, from the first conceptual design in 1980, to the present day situation. The issue of final disposal of sludge still remains unsolved, which poses a big problem in the operation and maintenance of this plant. Possible procedures for final treatment and disposal of sludge generated at the Zagreb wastewater treatment plant are presented in full detail.

Key words:

sludge from the wastewater treatment plant, use of sludge energy level, use of sludge in agriculture

Stručni rad

Stanislav Tedeschi, Davor Malus, Dražen Vouk

\section{Konačna obrada mulja otpadnih voda grada Zagreba}

Kod velikih uređaja za pročišćavanje otpadnih voda, ukupni su troškovi obrade mulja znatni i približno su jednaki troškovima osoblja. U radu se na pregledan način analizira problematika uređaja za pročišćavanje otpadnih voda grada Zagreba od njegovog prvog idejnog rješenja 1980. godine do danas. Pitanje konačne obrade mulja još uvijek nije riješeno što predstavlja veliki problem u radu i održavanju uređaja. Mogući postupci 


\section{Introduction}

The Wastewater Treatment Plant of the City of Zagreb (CUPOVZ) was built for the capacity of 1.2 million population equivalents, and for the biological treatment. When the CUPOVZ was initially designed, possible enlargement of the device was anticipated, for the capacity of up to 1.5 million of population equivalents, and for the tertiary treatment.

The plant is currently in operation and its treatment efficiency is very good, which is why it could well become a role model of a good quality wastewater treatment plant (WWTP) realized in our region. However, the problem of final disposal of sludge has still not been resolved, which is becoming a growing problem in the operation and maintenance of the CUPOVZ.

The problem of final disposal of sludge has not been properly resolved to this day in Croatia, and it has not even been dealt with through regulations, instructions or guidelines. As the construction of WWTPs is becoming more and more commonplace in Croatia, the sludge disposal is expected to increasingly encumber operation of municipal utility organizations, which are responsible for wastewater treatment and disposal. All solutions presented to remedy the sludge problem at CUPOVZ, from initial conceptual design solutions to present day concepts, are presented below.

\section{Sludge disposal solutions}

The first conceptual design for construction of the CUPOVZ at the present day location, with similar or greater capacity, was prepared already in 1980 [1]. The CUPOVZ project was discussed at many conferences and a number of papers were published in professional journals, while the problem of sludge disposal was raised already at very first conferences $[2$, 3]. At that time, it was emphasized that the conceptual design anticipates the final use of sludge in agriculture, which would come after the sludge is used as a source of energy.

The use of energy was anticipated in the procedure of anaerobic stabilisation, i.e. biogas production. The stabilized sludge would then be heated at the temperature of $200^{\circ} \mathrm{C}$ using the heat gained by burning the unused remains of the solid waste. The incinerator was to be located immediately next to the CUPOVZ, Figure 1.

In addition to the above mentioned sludge treatment facilities, the sludge drying fields were also anticipated in case the work stops at one of the sludge treatment facilities. As the plant was to be realized in two phases, two possibilities were considered for sludge treatment in the first phase: disposal at controlled landfill, or composting with other waste.

The biogeochemical cycle of mass circulation in biosphere is actually closed through the use of mud in agriculture.

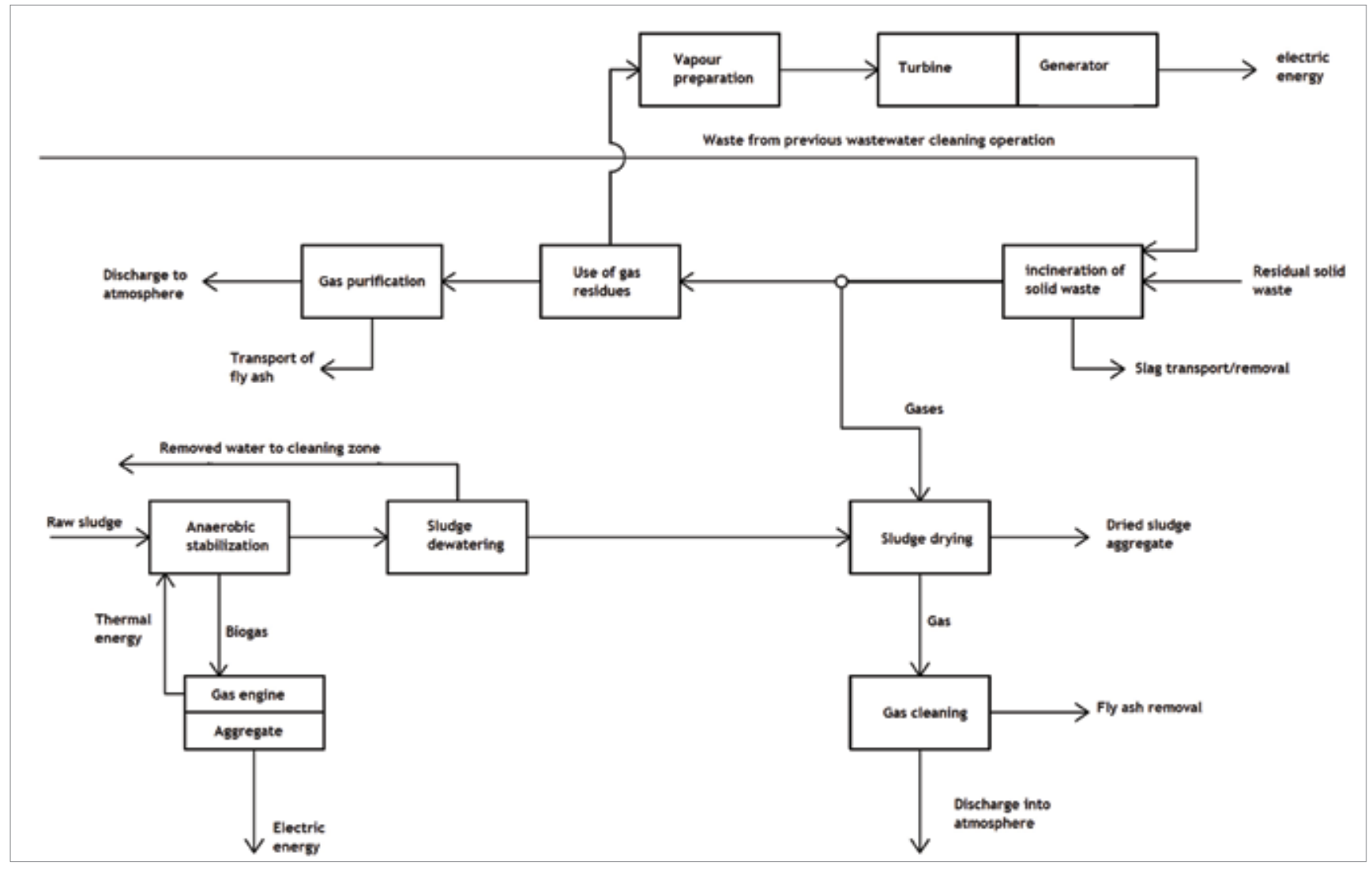

Figure 1. Schematic view of the sludge drying device 
The dried sludge contains 90 percent or more of dry matter. By heating at about $200^{\circ} \mathrm{C}$, we obtain the aggregate that can easily be packed in bags and stored. If necessary it can be transported to greater distances, due to insignificant quantity of water in the sludge. The principal marketing advantage of dried sludge is mainly psychological. The sludge appears as "industrial" product and a mineral fertilize, rather than as "residual-faecal" material. Other advantages are:

- sanitary/hygienic safety,

- machines used for mineral fertilizer can also be used for sludge aggregate spreading,

- small storage area,

- no offensive odour.

The main drawback of the sludge drying procedure is considerable energy needed to remove excess water $\left(5,22 \times 10^{6} \mathrm{KJ} / \mathrm{t} \mathrm{H}_{2} \mathrm{O}\right)$. It was therefore anticipated to obtain necessary energy by building a solid waste incinerator right next to the sludge drying device. The energy balance calculation made in the scope of the conceptual design for the device was positive [4].

The use of sludge in agriculture was proposed as the Črnec field improvement project near Zagreb, aimed at converting this field into agricultural land, was considered at that time. However, as industrial waste water and some rainwater penetrate into the municipal waste water devices, the authorities decided that the use of sludge in agriculture would not be environmentally safe due to excessive heavy metal content in sludge.

During preparation of conceptual design for the plant [1], one of alternatives was to dry the mud and use the aggregate obtained in this way as fuel in industrial plants. In this case the sludge stabilization was not planned, and the process was to consist only of reduction of water quantity in raw sludge and drying, so as to keep the greatest possible level of energy in this aggregate.

In early 1980s no guidelines existed in Croatia as to the use of sludge in agriculture, and data were scarce about possible heavy metal content in sludge generated at CUPOVZ. This is why the Program for the Raw Sludge Study - Phase One was defined in the scope of preparation of the conceptual design for the first phase of the plant [5]. In the scope of this program, the Faculty of Agronomy of the University of Zagreb, i.e. its Plant Nutrition Department, conducted multidisciplinary study for investigating possible use of raw sludge in agriculture in the period from 1984-1989 [6].

The use was made of sludge produced at the pilot plant on the quasi-technical scale [7], and at the pilot plant on the technical scale, situated next to the main evacuation canal [8].

The study of possible use of sludge in agriculture showed that some possibilities of use do exist, but with appropriate level of caution and subject to further studies. It should be noted that IN Croatia wasn't a Byelaw on the limited use of sludge in agriculture [9] before March 1992, and so the regulations applied in other European countries had to be used.
The study called "An integral concept of waste and sludge management for the City of Zagreb" [10] was completed in 1993. All sludge management solutions known to that date are considered in that study. After a detailed analysis of solutions presented in the study, the following proposals were made:

- joint disposal of sludge and solid waste,

- additional treatment of sludge and solid waste prior to final disposal,

- incineration or composting is proposed as additional treatment,

- regardless of the proposed final disposal of sludge, anaerobic stabilization of sludge was also proposed, with biogas use and water removal.

It is also indicated in the Study that the wastewater sludge from the CUPOVZ could not be used in agriculture due to excessive concentration of heavy metals (chromium, zinc, lead). The authors of the study emphasize that the reduction in heavy metal content in sludge can not be expected even if the device for preliminary purification of industrial waste water is used [11]. According to the study [10], the sludge would be deposited together with other solid waste at the waste disposal site "Dumovečki lug", which was defined as "controlled disposal site" [12] in the Plan for Water Management in the City of Zagreb.

Because the idea of simultaneous construction of the plant and the controlled disposal site seemed unsafe to authorities, it was finally indicated in the Invitation to Bid for construction of the CUPOVZ that the stabilized sludge, freed from surplus water, would be stored for the first two years at the temporary stockpile situated to be organized within the plant premises, Figure 2. It was consequently specified in Section 6.11 of the Concession Agreement that the city will provide at no additional cost a sludge disposal site, outside of the plant premises, and this until final acceptance of the plant at the latest. In case the City does not provide a disposal site outside of the plant premises, the Concessionary is authorized to organize and conduct appropriate sludge disposal and to charge the City a mutually agreed fee for such disposal.

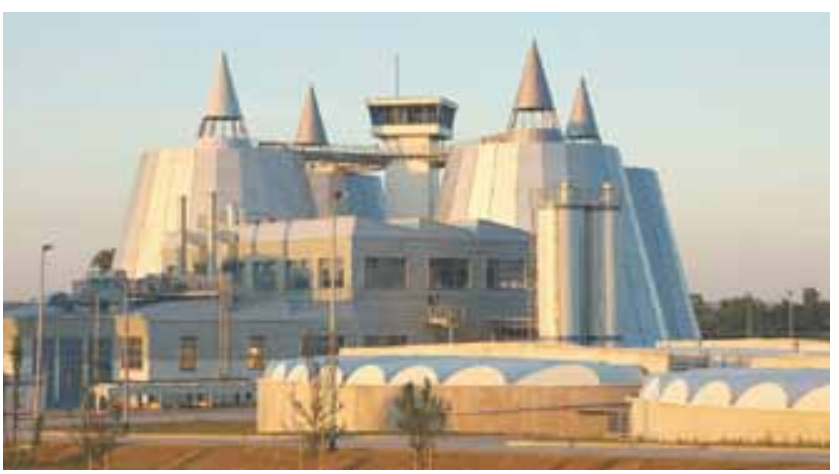

Figure 2. Sludge treatment (thickening, anaerobic stabilisation, dehydration) 

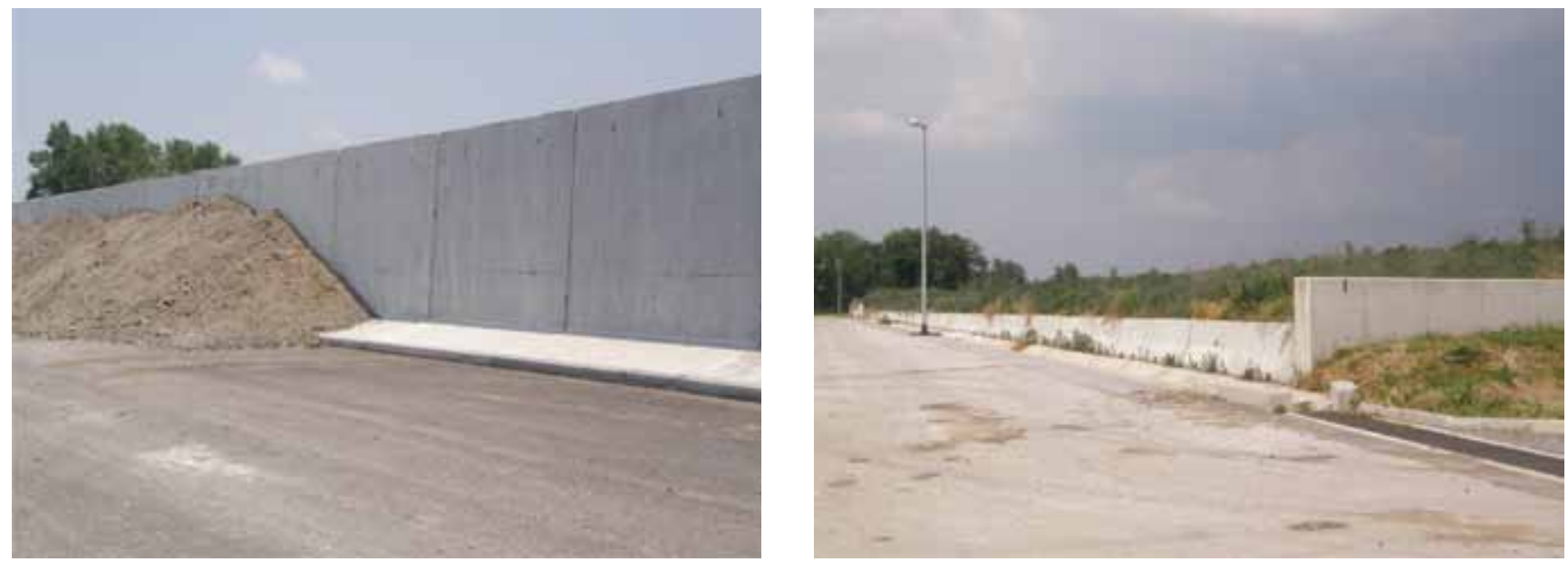

Figure 3. Temporary stockpile of stabilized and dehydrated sludge (at the plant premises)

Since 2007 , an average quantity of 52,400 tons of sludge was stored at CUPOVZ premises every year. Based on available storage area within the plant, it is presently estimated that it will be possible to store sludge at CUPOVZ premises until the end of 2013, Figure 3.

The ECOCYCLING procedure for sludge treatment at CUPOVZ premises was proposed in 2009 [14]. The ecocycling procedure enables conversion of solid waste, including sludge from municipal plants, into a secondary raw material. Thermal treatment is not needed, and there are no residues or offensive odours. In the course of this procedure, the waste is pulverized and mixed with natural additives such as clay, minerals, lime, or chemicals available on the market. Depending on the type of waste and additives, and on the procedure itself, the process results in production of an inert and stable substance that can be used in civil engineering (production of concrete products), or in forestry and agriculture for soil improvement. Prior to the use of ecocycling procedure in the treatment of sludge stocked at CUPOVZ premises, it is necessary to investigate possible marketing potential, and also agricultural or forest land where for instance fast-growing trees could be planted and subsequently used as biomass in energy production. Considering the huge annual mass of sludge generated at CUPOVZ premises and market uncertainties, and due to insufficient references about use of ecocycling procedure on big plants, the decision was made not to consider this method in further analysis.

In keeping with Concession Contract, the Concessionaire continued to investigate other possibilities for final disposal of sludge. The conceptual design for sludge disposal was completed in 2010 [15].

After the short-term and long-term analysis of stabilized and dewatered sludge production, the authors of the Study proposed, as the only short term solution in case no other facility for long-term disposal of sludge is built, that the sludge be transported to a temporary stockpile, either in or outside of Croatia.
As to long-term solution of the problem, the following possibilities were considered:

- monothermal process

- simultaneous thermal processing in

- thermal waste treatment plant,

- coal-fired thermal power station,

- cement plant,

- use for agricultural purposes.

Various aspects such as investment cost, operation and maintenance costs, and availability of agricultural land, were considered.

According to results of sludge testing conducted at CUPOVZ premises by the Zagreb Institute of Public Health "Andrija Štampar", the content of heavy metals, organic substances and pathogenic microorganisms in this slag is within limits set for treated sludge used in agriculture. The testing was made in compliance with the Byelaw on Agricultural Land Protection [9] and Byelaw on the Management of Sludge Generated by Wastewater Treatment Plants and Destined for Use in Agriculture [16].

These positive results are the consequence of reduced industrial activity in Zagreb, and hence of reduced discharge of waste water containing heavy metals, but also of growing use of unleaded petrol.

According to the byelaw on sludge management [16], no more than 1.66 tons of dry sludge may be used each year per hectare of agricultural land. According to the conceptual study made with regard to sludge management, the quantity of dewatered sludge for the final planned size of the plant is 1.5 million of population equivalents. This value is increased by the quantities currently stored at temporary stockpile sites, which also have to be disposed of in a permanent way. After elimination of existing sludge storages, it may be opportune to consider the idea of finally discharging the sludge generated at the wastewater treatment plant in the immediate vicinity of Zagreb. This is why it is estimated in the long-term sludge disposal concept that the total sludge mass will amount of 
80,000 tons annually, while the dry matter is estimated at 30,200 tons annually.

The area of 18,200 hectares of agricultural soil, meeting allowable values for heavy metal content in soil as specified in the sludge management byelaw [16], will be required for the quantity of $30,200 \mathrm{~kg}$ of dry matter per year.

It is specified in the Conceptual sludge management study that a part of the sludge could be used for agricultural purposes, but not the entire quantity of sludge stored at CUPOVZ.

After the comprehensive analysis of other solutions, and taking into account environmental protection costs, it was concluded that the procedure involving monothermal treatment would be the most favourable concept for the final disposal of sludge.

The City of Zagreb has prepared the Draft Plan for Waste Management in the City of Zagreb for the period until 2015 [17]. The Draft Plan for Waste Management covers the total waste generated in Zagreb, namely:

- municipal waste,

- non-hazardous production waste,

- special waste,

- other waste,

- hazardous waste.

The waste sludge generated in CUPOVZ has been classified as "other waste" and, according to the Regulation on categories, types and classification of waste, with the catalogue of waste and list of hazardous waste, this sludge has been included in group 190805 of waste generating activities [18].

The Draft Plan for Waste Management in Zagreb is compliant with the Waste Management Strategy of the Republic of Croatia [19], Plan for Waste Management in the Republic of Croatia [20], Strategy of Sustainable Development of the Republic of Croatia [21], and the Program of Environmental Protection in the City of Zagreb [22], and has also been harmonized with the new EU directive 2008/98 EC on waste.

According to the Draft Plan, the plant for thermal treatment of municipal waste is to be built at the Žitnjak East District (Resnik) in Zagreb (according to the environmental impact assessment for the "Thermal Waste Treatment Plant in the City of Zagreb", the plant will be located within the CUPOVZ premises).

Generation of energy will be the main objective of the thermal treatment of waste. Two incineration methods are available for such types of waste-fired power plants:

- moving grate incineration,

- fluidised bed incineration.

The combustion residue (slag) is to be used in civil engineering applications, and a construction of a storage area at Prudinec is planned to accommodate possible surplus combustion residue. Additional treatment and export is planned for fly ash, i.e. for ash resulting from flue gas cleaning.

With constant checking of heavy metal content in ash resulting from sludge incineration, and in soil onto which this ash is deposited, the fly ash generated by sludge incineration could be used in agriculture and similar applications in quantities of 10-15 tons/year per hectare of agricultural land [23]. In fact, the value of fly ash in thermal treatment of sludge (without municipal waste) is reflected in phosphate content of $10-20 \%$ [23]. This phosphate content is exclusively characteristic for plants equipped for the level three cleaning. According to the Decision on Identification of Sensitive Areas (Official Gazette 81/10), the CUPOVZ plant is to be improved by adding the level three cleaning (removal of nutrient salts of nitrogen and phosphorus). The total quantities of phosphorus available on Earth are limited, and as the part of phosphorus used in agriculture is lost in rivers and deep seas, there is a potential hazard of lack of usable phosphorous compounds on Earth, and that this lack could be the limiting factor in agricultural production.

In Austria, where the thermal treatment of sludge is the only solution for the long-term disposal of sludge in big cities such as Vienna, Linz, Graz and others, much consideration is now given to the idea of replacing joint thermal treatment, i.e. incineration together with other solid waste, by the monothermal treatment of sludge, so that phosphorus can be recycled from ash [24]. In fact, a recent Vienna-based centre for thermal treatment of waste (Simmeringer Haide) is a good example of how municipal waste, hazardous waste and sludge can be incinerated separately each in its own furnace (facility), taking into account specific features of each type of waste. The capacity of this centre is $200,000 \mathrm{t}$ /year of sludge, 100,000 t/year of hazardous waste, 100,000 t/year of municipal waste and 4,000 t/year of old car batteries.

New sludge disposal regulations that are currently being prepared in Austria will place emphasis on the use of principal components of sludge, and to the related monothermal treatment of sludge, as in case of joint incineration the resulting ash represents the phosphorus that is lost from the biogeochemical cycle on Earth.

It is indicated in the Draft Plan [17] that energy is the main product of thermal treatment, and so the municipal waste is classified, based on the relevant EU Directive, among renewable source of energy that enjoy financial and other support in developed countries of the world.

If a similar concept is to be applied in Zagreb, it will be possible to build a waste sludge incinerator as a separate facility, but within the sludge incineration centre on the same location, i.e. the overall centre would be realized in several steps. The waste resulting from incineration, and ash coming from the air cleaning device, would be disposed of together, in full accordance with the Draft Plan for waste management, Figure 4.

It is not expressly specified in the Draft Plan that the thermal treatment of remaining municipal waste and sludge must be conducted in a single facility (furnace), and so the construction of a separate facility for thermal treatment of sludge would be compliant with the Draft Plan.

According to the Draft Plan, the construction of facilities for the thermal treatment of municipal waste, non-hazardous waste from production, and sludge from CUPOVZ, would 


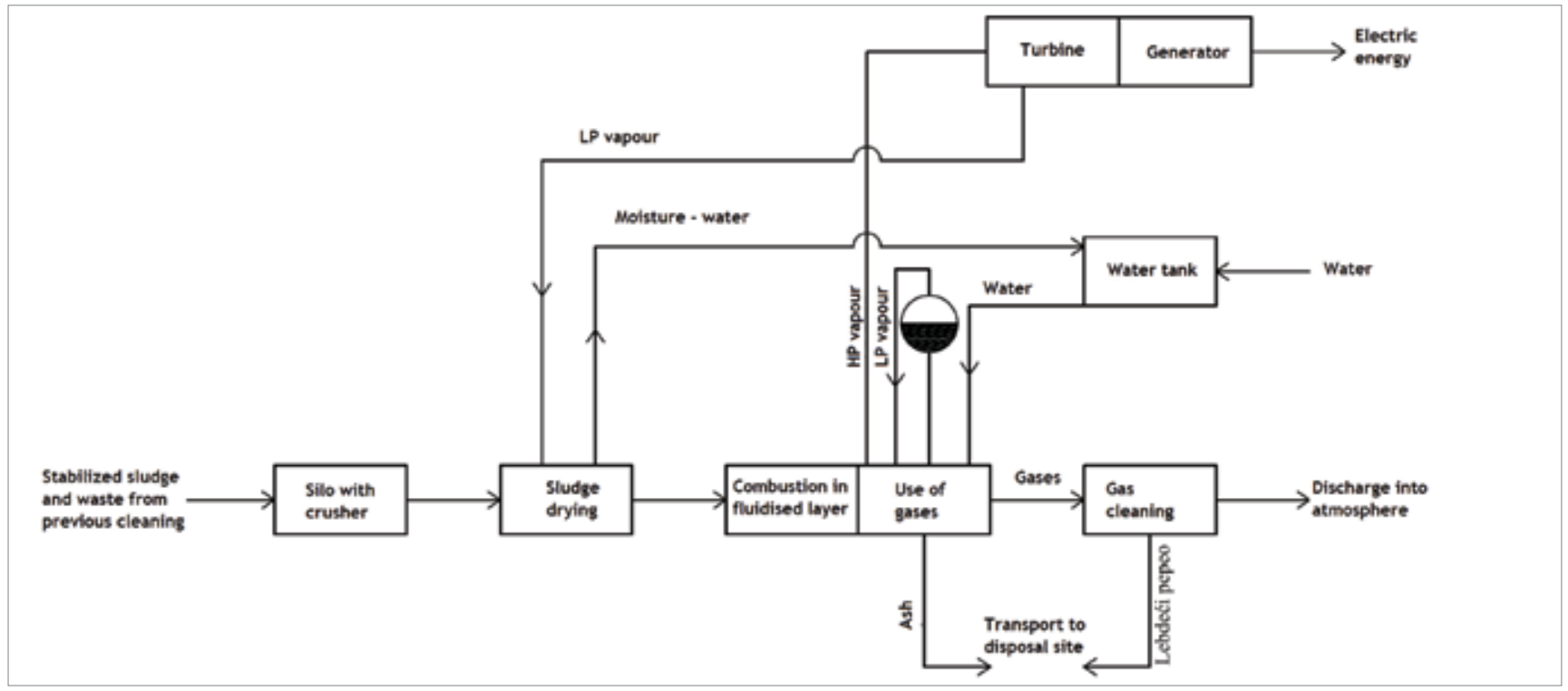

Figure 4. Schematic view of monothermal treatment of sludge

commence in 2013, while the start of preliminary activities (studies, location, etc.) is set for 1 September 2009.

As the Draft Plan has not as yet been adopted as the Waste Management Plan, all dates must be put off for at least two years, and so the construction of the thermal treatment plant would start approximately in 2015 in case all works, and especially preliminary activities, are carried out without interruption. According to the Conceptual Study for sludge disposal, in case the final sludge disposal is not resolved by 2013, the only solution would be to transport the sludge to an external location. Based on the above considerations, the Concessionaire has ordered the Study on monothermal treatment of sludge. This study on the monothermal treatment of sludge comprises all activities that are needed for plant construction, including additional activities related to environmental protection [25]. The mono-incinerator would be located in the immediate vicinity of sludge stabilisation and dewatering facilities, Figure 5. The time needed for design preparation, procurement of necessary permits, and realization of civil engineering, mechanical and electrical works, would amount to about four years. As the decision on the final disposal of sludge has not as yet been made, it can easily be concluded that an unnecessary spending of considerable funds for the transport sludge to an external location is going

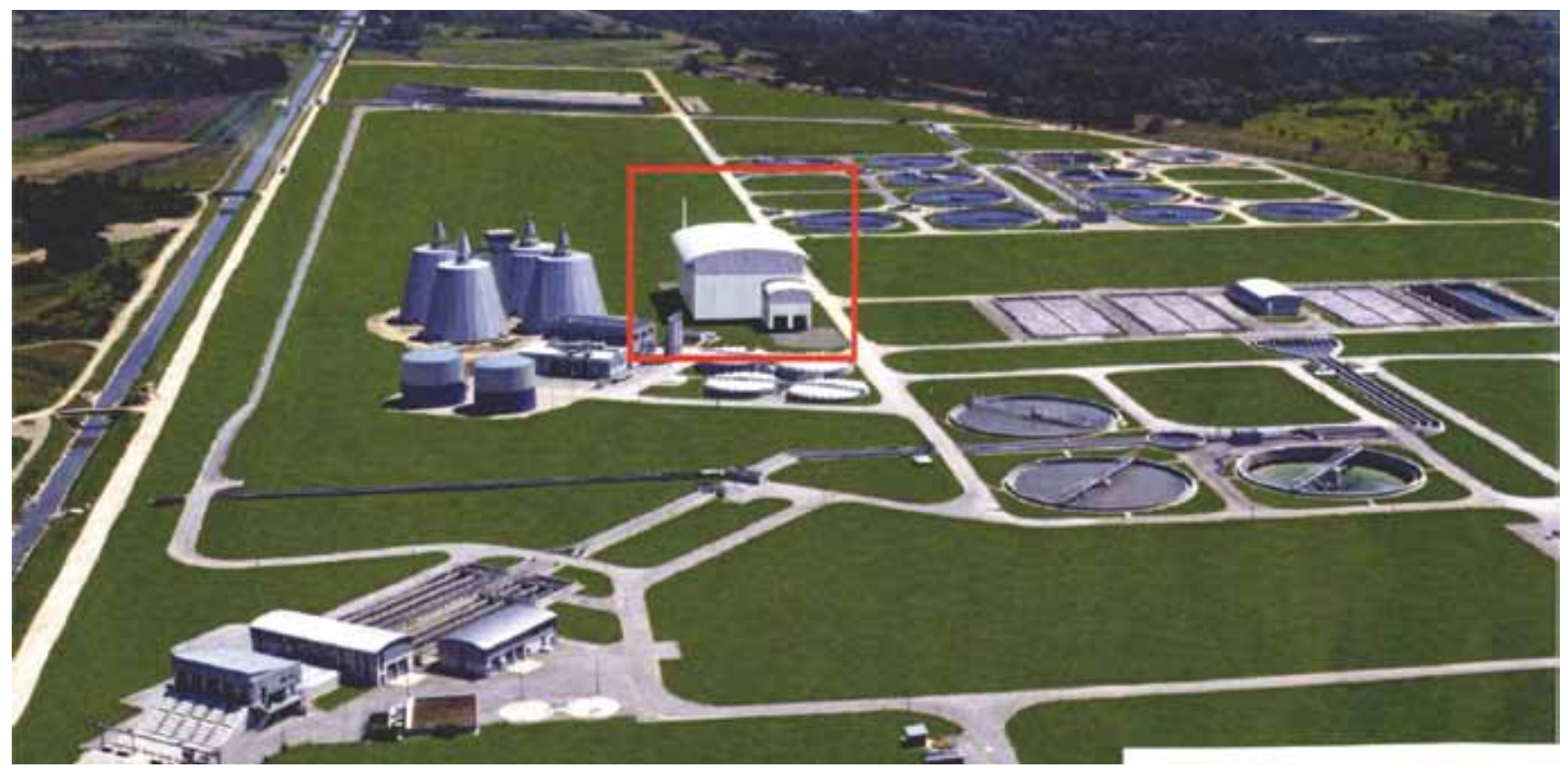

Figure 5. View of CUPOVZ with an area for thermal treatment of sludge marked in red 
to start. To further clarify this statement, it might be added that annual sludge transport costs, for instance its transport to Hungary, would amount to about $10 \%$ of the costs needed to build a plant for the monothermal treatment of sludge.

\section{Conclusion}

Various solutions for the treatment and final disposal of sludge at CUPOVZ have been considered and studied for more than three decades now but the final decision has still not been made. From initial solutions to this day the sludge has never been considered as a worthless waste, but has always been valued for its level of energy, and for the content of

\section{REFERENCES}

[1] Građevinski institut - OOUR Fakultet građevinskih znanosti Zagreb i Inženjerski projektni zavod (1980.): Idejno rješenje uređaja za perspektivne potrebe grada. Samoupravna interesna zajednica za vodno područje sliva Save, Zagreb.

[2] Tedeschi, S.; Ondruš, M. (1981.): Tehnička dokumentacija uređaja za pročišćavanje otpadnih voda grada Zagreba. Simpozij „Dani zaštite čovjekove sredine". Stalna konferencija gradova i općina Jugoslavije, Zagreb, 10.06.1981.

[3] Tedeschi, S. (1981.): Prikaz sustava za pročišćavanje kanalskih voda grada Zagreba. Zbornik savjetovanja „Akumulisanje, tretman i evakuacija vode", Subotica, 20.30.10.1981. Opće udruženje za vodoprivredu Jugoslavije, 122-135.

[4] Tedeschi, S. (1981.): Mogućnost korištenja mulja iz otpadnih voda grada Zagreba. Građevinar, [33] 1981., 5, 219-224.

[5] Građevinski institut - OOUR Fakultet građevinskih znanosti Zagreb i Inženjerski projektni zavod Zagreb (1982.): Idejni projekt prve faze uređaja kod Ivanje Reke. Samoupravna vodoprivredna interesna zajednica za vodno područje sliva Save, Zagreb.

[6] Agronomski fakultet Sveučilišta u Zagrebu - Zavod za ishranu bilja (1992.): Izvještaj o rezultatima istraživanja primjene otpadnog mulja u poljoprivredi. Samoupravna vodoprivredna interesna zajednica za vodno područje sliva Save, Zagreb.

[7] Građevinski institut - OOUR Fakultet građevinskih znanosti Zagreb (1986.): Istraživački radovi na pilot uređaju u polutehničkom mjerilu. Samoupravna vodoprivredna interesna zajednica za vodno područje sliva Save, Zagreb.

[8] Građevinski institut - OOUR Fakultet građevinskih znanosti Zagreb (1989.-1991.): Istraživački radovi na pilot uređaju za pročišćavanje otpadnih voda grada Zagreba. Samoupravna vodoprivredna interesna zajednica za vodno područje sliva Save, Zagreb.

[9] Pravilnik o zaštiti poljoprivrednog zemljišta od onečišćenja štetnim tvarima. Narodne novine 15, 25.03.1992.

[10] TBU - Innsbruck, ITU Berlin, SFC - Salzburg (1993.): Cjeloviti koncept gospodarenja otpadom i muljem grada Zagreba. Zbrinjavanje gradskog otpada i sanacija, Zagreb. nutrients, which could be used to improve soil in agriculture, and also in forestry. It should be noted that from the very first conceptual design the experts have estimated that joint disposal of sludge and solid (especially municipal) waste on the same location would be highly beneficial.

After many years of analysis it now seems that, according to present day documentation, the final treatment of sludge and municipal waste will be conducted at the CUPOVZ premises. The thermal treatment, with prior use of energy, is anticipated in this context. Experience gained in other countries shows that the possibility of using the residual substance - in this case the ash - for improving soil - should also be taken into consideration.

[11] Tedeschi, S.; Višić, I. (1996.): Mogućnosti izgradnje uređaja za čišćenje otpadnih voda grada Zagreba. Zbornik Sabora hrvatskih graditelja '96 - "Graditeljstvo u obnovi i razvitku Republike Hrvatske", Cavtat, 07.-09.11.1996. Hrvatsko društvo građevinskih inženjera, 985-990.

[12] Elektroprojekt (1986.): Vodoprivredna osnova grada Zagreba - Općine Samobor i Sesvete. Grad Zagreb, Gradski komitet za prostorno uređenje i komunalne poslove.

[13] Grad Zagreb (1998.): Koncesija pročišćavanja otpadnih voda Poziv za natječaj.

[14] Global energy invest (2009.): Obrada komunalnog otpada i otpadnog mulja metodom ECOCYCLING. Dalekovod, Zagreb

[15] Kocks Consult GmbH (2010.): CUPOV Zagreb, Hrvatska, Konceptualna studija zbrinjavanja otpadnog mulja. Zagrebačke otpadne vode, Zagreb.

[16] Pravilnik o gospodarenju muljem iz uređaja za pročišćavanje otpadnih voda kada se mulj koristi u poljoprivredi. Narodne novine 38, 02.04.2008.

[17] Grad Zagreb: Nacrt plana gospodarenja otpadom u gradu Zagrebu za razdoblje do 2015. godine (2009.). Gradski ured za gospodarstvo, Zagreb.

[18] Uredba o kategorijama, vrstama i klasifikaciji otpada s katalogom otpada i listom opasnog otpada. Narodne novine 50, 18.04.2005.

[19] Strategija gospodarenja otpadom Republike Hrvatske. Narodne novine 130/2005.

[20] Plan gospodarenja otpadom u Republici Hrvatskoj za razdoblje 2007.-2015. godine. Narodne novine 85/2007.

[21] Strategija održivog razvitka Republike Hrvatske. Narodne novine 30/2008.

[22] Program zaštite okoliša grada Zagreba. Službeni glasnik grada Zagreba 8/1999.

[23] OTV (1997.): Traiter et Valoriser les Boues. Liguge (France): Aubin Imprimeurs, 457 str.

[24] Müller, H. (2009): Wastewater sludge management under Austria's federal framework. "Water 21”, 2009, 12, 32-33.

[25] EVN umweltholding (2010.): Koncept postrojenja za monospalionicu otpadnog mulja Zagreb. Zagrebačke otpadne vode, Zagreb. 